\title{
Investigation of flue gas water-alternating gas (flue gas-WAG) injection for enhanced oil recovery and multicomponent flue gas storage in the post-waterflooding reservoir
}

\author{
Zhou-Hua Wang $^{1} \cdot$ Bo-Wen Sun ${ }^{1} \cdot$ Ping Guo ${ }^{1} \cdot$ Shuo-Shi Wang ${ }^{1} \cdot$ Huang Liu ${ }^{1} \cdot$ Yong Liu ${ }^{3,4} \cdot$ Dai-Yu Zhou $^{2} \cdot$ Bo Zhou $^{3,4}$
}

Received: 30 July 2020 / Accepted: 8 December 2020 / Published online: 8 February 2021

(C) The Author(s) 2021

\begin{abstract}
Flue gas flooding is one of the important technologies to improve oil recovery and achieve greenhouse gas storage. In order to study multicomponent flue gas storage capacity and enhanced oil recovery (EOR) performance of flue gas water-alternating gas (flue gas-WAG) injection after continuous waterflooding in an oil reservoir, a long core flooding system was built. The experimental results showed that the oil recovery factor of flue gas-WAG flooding was increased by $21.25 \%$ after continuous waterflooding and flue gas-WAG flooding could further enhance oil recovery and reduce water cut significantly. A novel material balance model based on storage mechanism was developed to estimate the multicomponent flue gas storage capacity and storage capacity of each component of flue gas in reservoir oil, water and as free gas in the post-waterflooding reservoir. The ultimate storage ratio of flue gas is $16 \%$ in the flue gas-WAG flooding process. The calculation results of flue gas storage capacity showed that the injection gas storage capacity mainly consists of $\mathrm{N}_{2}$ and $\mathrm{CO}_{2}$, only $\mathrm{N}_{2}$ exists as free gas phase in cores, and other components of injection gas are dissolved in oil and water. Finally, injection strategies from three perspectives for flue gas storage, EOR, and combination of flue gas storage and EOR were proposed, respectively.
\end{abstract}

Keywords Flue gas storage $\cdot$ Enhanced oil recovery $\cdot$ Flue gas water-alternating gas $\cdot$ Material balance model $\cdot$ Injection strategy

\section{Introduction}

Edited by Yan-Hua Sun

Bo-Wen Sun

sbwswpu@163.com

Ping Guo

guopingswpi@vip.sina.com

1 State Key Laboratory of Oil and Gas Reservoir Geology and Exploitation, Southwest Petroleum University, Chengdu 610500, Sichuan, China

2 Research Institute of Exploration and Development, PetroChina Tarim Oilfield Company, Korla 841000, Xinjiang, China

3 Research Institute of Experiment and Detection, PetroChina Xinjiang Oilfield Company, Karamay 834000, Xinjiang, China

4 Xinjiang Laboratory of Petroleum Reserve in Conglomerate, Karamay 834000, Xinjiang, China
Flue gas is one of the primary sources of human-made greenhouse gases, which contains a large amount of $\mathrm{N}_{2}$, $\mathrm{CO}_{2}$, and $\mathrm{SO}_{2}$ emitted in the process of fuel combustion and during cement production (Majeed and Svendsen 2018). The composition of the flue gas is varied with different combustion materials in the combustion process, which is mainly composed of $\mathrm{N}_{2}$ and $\mathrm{CO}_{2}$, and the air-polluting components such as $\mathrm{NO}_{x}, \mathrm{CO}, \mathrm{H}_{2} \mathrm{~S}$, and dust may also exist in flue gases (Bürkle et al. 2018).

$\mathrm{CO}_{2}$ and non- $\mathrm{CO}_{2}$ emissions generated by fuel combustion process can be sequestered in underground geologic formations such as deep saline aquifers (Bachu 2015), coal, oil, and gas reservoirs (Agartan et al. 2018; Li et al. 2006a, b), even fractured shale formations (Edwards Ryan et al. 2015). The geological sequestration has been proved to be a feasible technique for reducing greenhouse gas and helping tackle climate change. There are four basic mechanisms required for long-term successful geological $\mathrm{CO}_{2}$ storage: stratigraphic/structural, residual, solubility, and mineral 
trapping (Santibanez-Borda et al. 2019). If there is a good seal, $\mathrm{CO}_{2}$ will be trapped permanently and will be immobile with the contribution of these mechanisms. Many studies in the literature discuss $\mathrm{CO}_{2}$ storage and EOR (Bachu et al. 2004; Ettehadtavakkol et al. 2014; Farajzadeh et al. 2020; Gozalpour et al. 2005; Godec et al. 2011; Jia et al. 2019; Zhang et al. 2015) that have been proved to be effective techniques due to their high displacement efficiency, low cost, and high efficiency in reducing global warming phenomenon. However, only a few pieces of research have been investigated on flue gas injection in reservoirs (Dong and Huang 2002; Fong et al. 1992; Fossum et al. 1992; Liu et al. 2011; Srivastava et al. 1999; Shokoya et al. 2005; Trivedi and Babadagli 2005; Trevisan et al. 2013). The majority of flue gas injection studies were focused on maximizing the oil recovery, not flue gas storage. Recently, many studies have been conducted to remove $\mathrm{CO}_{2}$ and $\mathrm{SO}_{2}$ from flue gas independently (Lee et al. 2002; Liu et al. 2009; López et al. 2007; Sumathi et al. 2010a, b; Yi et al. 2014). However, the methods proposed in these studies have the disadvantages of either high-energy consumption or expensive equipment cost. Injecting raw flue gas into oil reservoirs is very attractive because these reservoirs have structural seals that are well studied and characterized for trapping. Flue gas can remain stored securely by virtue of following trapping mechanism: trapping beneath an impermeable layer, retention as an immobile phase in pore space of porous storage formations, dissolution into formation fluids and adsorption on the organic matter in shale or coal reservoirs (Nasralla et al. 2015). Thus, injecting flue gas into oil reservoirs may result in incremental oil recovery and make the storage project more feasible. The project economic viability is deeply dependent on the availability of the flue gas source.

Methods used to determine the storage capacity of injection gas in gas flooding processes include experimental measurement, theoretical model, semiempirical formulas, and numerical simulation. Han et al. (2018) studied flue gas displacement and storage capacity after the waterflooding in a full-diameter long core taken from Xinjiang Oilfield in China; they found that flue gas flooding after waterflooding can further enhance oil recovery, but the key factor to obtain good development effect is to choose the right timing for gas injection. Zhou et al. (2019) investigated $\mathrm{CO}_{2}$ storage in the heavy oil reservoirs through long core experiments; they found that the $\mathrm{CO}_{2}$ storage ratio increases with cycle numbers and the reservoir pressure. For each test, the last cycle is the best choice for $\mathrm{CO}_{2}$ storage, and the $\mathrm{CO}_{2}$ storage ratio can reach as high as $60 \%$ under the injection pressure $5000 \mathrm{kPa}$. For theoretical model and semiempirical correlations, Shaw and Bachu (2002) proposed a correlation to determine $\mathrm{CO}_{2}$ storage capacity in oil reservoirs during $\mathrm{CO}_{2}$ flooding processes, which is a function of oil recovery factor, the volume of original oil in place (OOIP), and oil shrinkage. Bachu et al. (2007) proposed a correlation for estimating $\mathrm{CO}_{2}$ storage capacity in coal beds, oil and gas reservoirs, and deep saline aquifers. Following these correlations, new $\mathrm{CO}_{2}$ storage capacity correlations in deep saline aquifers based on material balance equation were proposed (Kopp et al. 2009a; b; van der Meer and Yavuz 2009; Zheng et al. 2010; Zhou et al. 2011). As examples of numerical simulation, Li et al. (2006a, b) used CMG simulator to study the $\mathrm{CO}_{2}$ sequestration in depleted oil and gas reservoirs; they found that once the reservoir pressure reaches a certain high level, only increasing the injection pressure cannot effectively enhance the storage capacity. However, much more capacity can be achieved by removing a portion of the remaining water.

Injection of $\mathrm{CO}_{2}$ or flue gas for the purpose of coupled sequestration-EOR process is appealing due to the fact that both goals of final recovery enhancement and greenhouse gas control would be established by employing this scheme (Berg et al. 2010, 2013). Some authors have published works addressing economic analysis of $\mathrm{CO}_{2}-\mathrm{EOR}$ projects (Ghomian et al. 2007; Jahangiri and Zhang 2011; Leach et al. 2011). Forooghi et al. (2009) proposed a methodology to optimize the coupled $\mathrm{CO}_{2}$-EOR process. His work is based on simulation of $\mathrm{CO}_{2}$ injection into North Sea chalk field. They investigated the effect of six parameters, namely injection scheme, injector and producer well type, well control mode, slug size and the WAG ratio, on the coupled $\mathrm{CO}_{2}-\mathrm{EOR}$ and sequestration process. They concluded that the water-alternating gas injection scheme using a mixture of $\mathrm{CO}_{2}$ and hydrocarbon gas is the optimum case. Zangeneh et al. (2013) optimized carbon dioxide sequestration and enhanced gas recovery in a natural gas reservoir in Iran. They concluded that injection of carbon dioxide at optimized conditions resulted in permanent storage of carbon dioxide in addition to production of residual gas in the reservoir. Bender and Akin (2017) studied the efficiency of flue gas injection compared to $\mathrm{CO}_{2}$ injection for simultaneous EOR and storage by a 3D compositional simulation model and investigated the effect of injected gas type, gas solubility, and operating parameters on flue gas storage and oil recovery. Snippe et al. (2020) studied the wormholing effect during $\mathrm{CO}_{2}$ storage and water-alternating gas injection. They reported new experimental and modeling work that provides the means for qualitative-to-quantitative field-scale predictions of these effects for all the different combinations of $\mathrm{CO}_{2}$-water injection of interest.

After the literature review, most research is related to pure gas $\left(\mathrm{CO}_{2}\right)$ storage and EOR, and there is little work published on multicomponent flue gas storage in reservoirs. The majority research of flue gas storage is carried out by numerical simulation, and there is little simple theoretical model for multicomponent flue gas storage. This work is targeting multicomponent flue gas storage capacity, individual component storage capacity distribution characteristics, and EOR 
of flue gas-WAG injection after continuous waterflooding in oil reservoir. First, a long core experiment system for flue gas-WAG injection tests after continuous waterflooding was built. Second, a novel material balance model based on storage mechanism was developed to estimate flue gas storage capacity and individual component storage capacity distribution characteristics in the reservoir. Third, injecting strategies from three perspectives for flue gas storage, EOR, and combination of flue gas storage and EOR were studied. The outcome of this work provides an experimental evaluation method for flue gas storage and EOR in flue gas drive.

\section{Experimental}

\subsection{Experimental apparatus}

To perform a flue gas storage experiment, we set up a long core displacement device. It mainly includes an injection system, a core holder system, and a recovery system. A schematic of the experimental setup is presented in Fig. 1. The key part of the apparatus is the core holder, manufactured by Hai-An Petroleum Equipment Manufacturing Co., Jiangsu, China, which is installed in an air bath oven with a temperature range from 0 to $200{ }^{\circ} \mathrm{C}$ and the maximum working pressure of $70 \mathrm{MPa}$. The reservoir fluids, injection gas, and reservoir brine were injected into the core holder by three Ruska automatic pumps, respectively, which were connected to the left side of the core holder. A cathetometer monitored the volume of the injection sample. A low-temperature separator arranged at the end of the core holder was utilized to separate oil and gas. To ensure the accuracy of the measurement, the temperature readers, the pressure transducers, and the volume of the injection pump were calibrated frequently before the start of the experiment; the error ranges of temperature, pressure, and volume are $\pm 0.1{ }^{\circ} \mathrm{C}, \pm 0.05 \mathrm{MPa}$, and $\pm 0.1 \mathrm{~cm}^{3}$, respectively).

\subsection{Materials}

Materials used in this work include long cores, reservoir fluids, flue gas, and reservoir brine. The long cores were collected from Well H18 drilled in Karamay Oilfield, northwest China. The total length of the long core is $90.55 \mathrm{~cm}$, and it is composed of 14 sandstones and conglomerate cores. The average permeability of the assembled long core is $348.12 \mathrm{mD}$, and the pore volume (PV) and hydrocarbon pore volume (HCPV) are 232.9 and $137 \mathrm{~cm}^{3}$, respectively. More information about the long cores is listed in Table 1. Crude oil and gas were collected from a medium-permeability oil reservoir in China (Karamay Oilfield) using the separator sampling method. The reservoir temperature, pressure, and gas/oil ratio $(G O R)$ are $42{ }^{\circ} \mathrm{C}$, $8 \mathrm{MPa}$, and $36.9 \mathrm{~m}^{3} / \mathrm{m}^{3}$, respectively. The reservoir fluid was prepared in a laboratory by recombining the separator oil and separator gas according to a Chinese standard (GB/T 269812011). The compositions of separator gas, separator oil, and

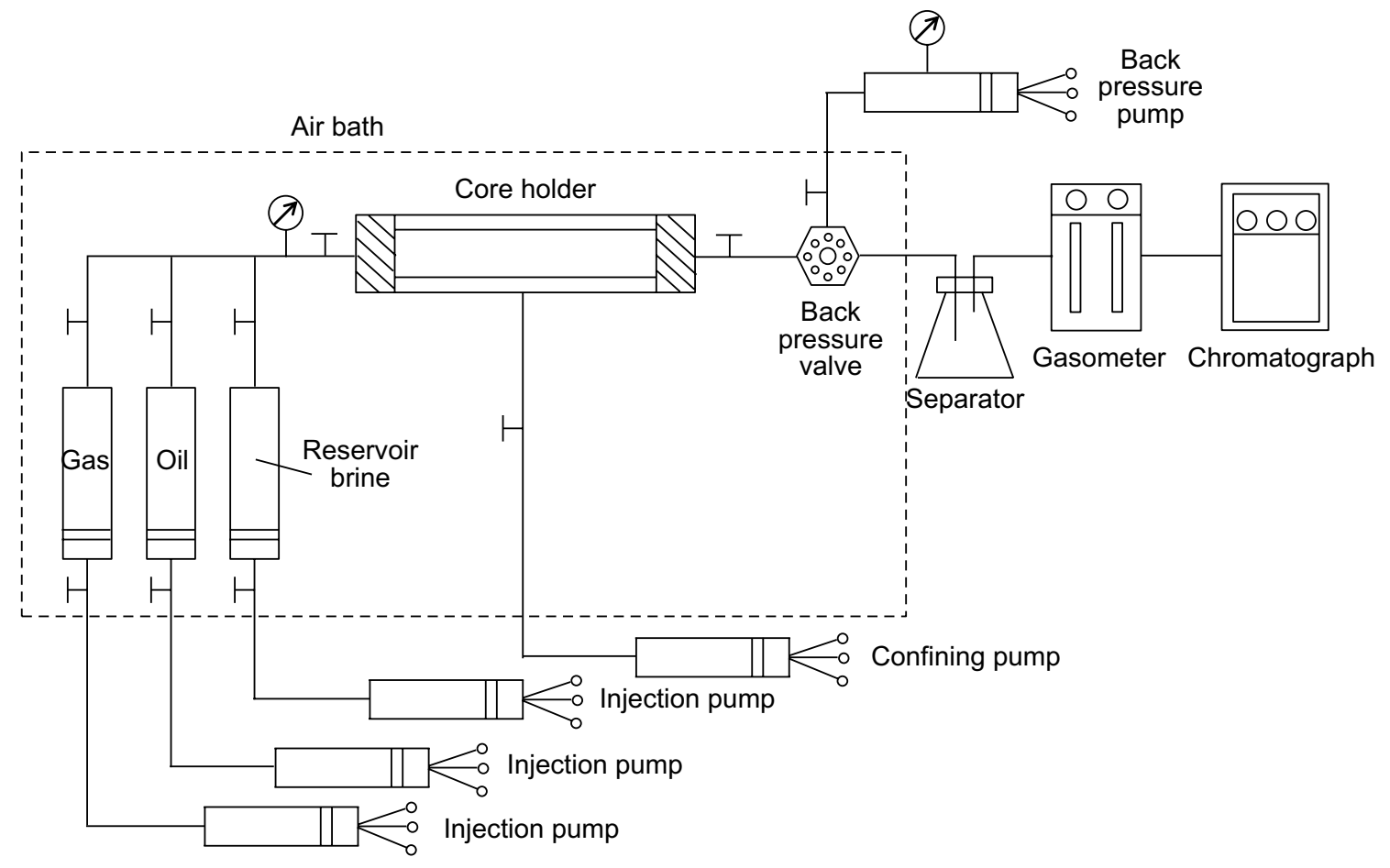

Fig. 1 Schematic of experimental setup for flue gas water-alternating gas injection test 
Table 1 Physical properties of the cores used

\begin{tabular}{llllll}
\hline No. & Lithology & Length, $\mathrm{cm}$ & Diameter, cm & Porosity, \% & Permeability, mD \\
\hline 1 & Sandstone & 6.297 & 3.791 & 23.65 & 254.78 \\
2 & conglomerate & 4.738 & 3.794 & 22.80 & 285.08 \\
3 & Sandstone & 7.318 & 3.644 & 25.64 & 2238.08 \\
4 & Sandstone & 7.470 & 3.642 & 22.45 & 208.32 \\
5 & Sandstone & 7.771 & 3.647 & 23.63 & 199.94 \\
6 & Sandstone & 6.449 & 3.638 & 21.38 & 194.82 \\
7 & Sandstone & 7.303 & 3.649 & 23.41 & 190.65 \\
8 & Conglomerate & 7.158 & 3.782 & 23.16 & 423.06 \\
9 & Sandstone & 6.454 & 3.635 & 25.34 & 152.14 \\
10 & Conglomerate & 6.170 & 3.795 & 22.15 & 506.61 \\
11 & Sandstone & 7.513 & 3.645 & 26.07 & 146.24 \\
12 & Conglomerate & 5.527 & 3.798 & 24.56 & 835.52 \\
13 & Conglomerate & 5.673 & 3.798 & 23.13 & 657.12 \\
14 & Conglomerate & 4.714 & 3.805 & 952.04 & \\
\hline
\end{tabular}

Table 2 Compositions (mol\%) of separator gas, separator oil, and recombined reservoir fluid

\begin{tabular}{lccc}
\hline Component & Separator gas & Separator oil & $\begin{array}{l}\text { Recombined } \\
\text { reservoir fluid }\end{array}$ \\
\hline $\mathrm{CO}_{2}$ & 1.14 & 0.000 & 0.321 \\
$\mathrm{~N}_{2}$ & 1.11 & 0.000 & 0.312 \\
$\mathrm{C}_{1}$ & 96.2 & 0.000 & 27.054 \\
$\mathrm{C}_{2}$ & 0.99 & 0.088 & 0.639 \\
$\mathrm{C}_{3}$ & 0.14 & 0.344 & 0.991 \\
$i-\mathrm{C}_{4}$ & 0.09 & 0.209 & 0.463 \\
$n-\mathrm{C}_{4}$ & 0.07 & 0.801 & 1.700 \\
$i-\mathrm{C}_{5}$ & 0.03 & 0.296 & 0.508 \\
$n-\mathrm{C}_{5}$ & 0.01 & 1.515 & 2.563 \\
$\mathrm{C}_{6}$ & 0.01 & 6.885 & 9.743 \\
$\mathrm{C}_{7}$ & 0.23 & 1.495 & 1.883 \\
$\mathrm{C}_{8}$ & 0.00 & 3.932 & 4.197 \\
$\mathrm{C}_{9}$ & 0.00 & 4.357 & 4.142 \\
$\mathrm{C}_{10}$ & 0.00 & 7.712 & 6.608 \\
$\mathrm{C}_{11+}$ & 0.00 & 72.366 & 38.880 \\
\hline
\end{tabular}

the recombined reservoir fluids are listed in Table 2. Flue gas was prepared by special gas reservoir laboratory of Southwest Petroleum University in China, and the composition of flue gas is listed in Table 3. Brine used was prepared in the laboratory according to the composition of the real reservoir brine taken from well H18, and its composition is listed in Table 4.

\subsection{Flue gas-WAG injection tests}

In this work, to improve the accuracy of the experimental results, petroleum ether was used to clean the flow line. Then, the setup was dried with high-pressure nitrogen after cleaning. The pumps, pressure gauges, and the thermometers were calibrated under the test conditions. First, the cores were cleaned with toluene to remove organic material, and then the core was blow-dried with nitrogen and evacuated. All experimental devices were connected according to Fig. 1 with valves closed. The experimental procedures are as follows:

(1) After the assembled long cores (filter paper was placed at the core joint to weaken capillary end effect) were successively stored in the core holder, the temperature of the oven was increased to reservoir temperature gradually.

(2) The long core was saturated with filtered reservoir brine. Next, the inner pressure and confining pressure of the cores were increased gradually using the injection pump and confining pressure pump until the inner pressure was equal to the reservoir pressure, where the confining pressure of the cores was approximately $5 \mathrm{MPa}$ greater than the inner pressure.

Table 3 Compositions of flue gas

\begin{tabular}{lllllll}
\hline Component & $\mathrm{N}_{2}$ & $\mathrm{CO}$ & $\mathrm{CO}_{2}$ & $\mathrm{O}_{2}$ & $\mathrm{CH}_{4}$ & $\mathrm{H}_{2}$ \\
\hline Content, mol\% & 83.913 & 0.24 & 14.67 & 0.49 & 0.42 & 0.267 \\
\hline
\end{tabular}


Table 4 Composition and salinity of reservoir brine taken from Well H18

\begin{tabular}{llllllllll}
\hline Component, $\mathrm{mg} \mathrm{L}^{-1}$ & \multicolumn{1}{c}{} & & & Total salinity, mg L & Water type & $\mathrm{pH}$ \\
\hline $\mathrm{K}^{+}+\mathrm{Na}^{+}$ & $\mathrm{Ca}^{2+}$ & $\mathrm{Mg}^{2+}$ & $\mathrm{Cl}^{-}$ & $\mathrm{SO}_{4}{ }^{2-}$ & $\mathrm{HCO}_{3}{ }^{-}$ & $\mathrm{CO}_{3}{ }^{2-}$ & & \\
\hline 4739.16 & 140.16 & 110.24 & 6407.52 & 28.50 & 2488.07 & 0 & $13,913.65$ & $\mathrm{NaHCO}_{3}$ & 7.34 \\
\hline
\end{tabular}

(3) The prepared reservoir fluids were injected into core holder to replace the reservoir water in cores using an injection pump at an injection rate of $0.1 \mathrm{~cm}^{3} / \mathrm{min}$ until the water in the separator did not increase to ensure the cores only contained bound water and prepared reservoir fluids.

(4) Waterflooding was carried out until the water cut reached $100 \%$ (no oil production); afterward, the flue gas-WAG flooding with WAG slug size of $0.1 \mathrm{HCPV}$ was performed until the oil phase did not increase at the exit of the core holder, and the injection volume of flue gas-WAG flooding is 1.4 HCPV. The volume of injected water, flue gas, and produced fluid (oil, gas, water) with each injection of $0.1 \mathrm{HCPV}$ was recorded, and the production gas oil ratio of the exit of the core holder at different times was determined. The measurement uncertainties include the following: First, the pipeline volume has a certain influence on the quantitative injection; second, the dead volume at both ends of the core and the core holder should also be considered.

\section{Evaluation methodology}

Many theoretical models or semiempirical models of $\mathrm{CO}_{2}$ storage are proposed based on the material balance equation. The basic assumption is that the theoretical capacity for $\mathrm{CO}_{2}$ storage in oil reservoirs is equal to the volume previously occupied by the produced oil and water. The relevant researchers from USDOE, European Commission and the Carbon Sequestration Leadership Forum (CSLF) have further investigated the calculation methods for $\mathrm{CO}_{2}$ storage capacity in reservoir (U.S. DOE 2008; Bachu 2008), which were not involved in flue gas storage and waterflooded oil reservoirs. However, many oil fields are developed by waterflooding. Therefore, a new material balance model for estimating flue gas storage capacity and storage capacity of each component of flue gas in waterflooded oil reservoir was developed. The model was constructed according to the following assumptions:

(1) The injection and crude oil reach equilibrium instantaneously.

(2) The injection of gas and reservoir fluids contact completely.
(3) Chemical reactions between injection and reservoir fluids and rocks are not considered.

(4) Under the same temperature and pressure, the dissolution order of injection gas is determined according to the solubility of pure component gas.

(5) The phase effect between injection gas and dissolved gas of production gas is not included.

\subsection{Flue gas storage capacity}

Flue gas storage capacity was estimated according to the relationship between $G O R_{\mathrm{p}}$ (production gas oil ratio) and $G O R_{\mathrm{i}}$ (initial gas oil ratio). If $G O R_{\mathrm{p}} \leq G O R_{\mathrm{i}}$, we can obtain that the injection gas is not produced, which is completely stored in cores. Here, the storage capacity of injection gas is equal to cumulative injection gas volume. If $G O R_{\mathrm{p}}>G O R_{\mathrm{i}}$, it indicates that the injection gas has been produced at the exit of the holder. At the moment, the produced gas is composed of the gas dissolved in oil and the produced injection gas; the storage capacity of injection gas in reservoir can be calculated:

$V_{\text {sto,inj,g }}=V_{\text {cum,inj,g }}-\sum V_{\text {pro,inj,g }} \cdot B_{\mathrm{g}}$

$V_{\text {pro,inj,g }}=V_{\text {pro,g }}-G O R_{\mathrm{i}} \cdot V_{\text {pro,o }}$

where $V_{\text {sto,inj,g }}$ is the storage capacity of injection gas in cores, $\mathrm{cm}^{3} ; V_{\text {cum,inj,g }}$ is the cumulative injection gas volume, $\mathrm{cm}^{3}$; and $V_{\text {pro,inj,g }}$ is the volume of injection gas produced, $\mathrm{cm}^{3} ; B_{\mathrm{g}}$ is the volume factor of injection gas, $\mathrm{cm}^{3} / \mathrm{cm}^{3} ; V_{\text {pro,g }}$ is the produced gas volume, $\mathrm{cm}^{3}$; and $G O R_{\mathrm{i}}$ is initial gas oil ratio, $\mathrm{m}^{3} / \mathrm{m}^{3} ; V_{\text {pro,o }}$ is produced oil volume, $\mathrm{cm}^{3}$.

\subsection{Storage capacity of each component of flue gas in reservoir oil, water and as free gas}

Solubility of pure gas in reservoir oil and water is an important parameter for estimating storage capacity of each component of flue gas in reservoir (Ding et al. 2018). In this study, the solubility of $\mathrm{CO}_{2}, \mathrm{CH}_{4}, \mathrm{~N}_{2}$ and $\mathrm{O}_{2}$ in reservoir oil and water was determined respectively at $42{ }^{\circ} \mathrm{C}$ and $8 \mathrm{MPa}$ using single-flash method according to the composition of injection gas. Meanwhile, considering the risk of $\mathrm{CO}$ and $\mathrm{H}_{2}$, the solubility of $\mathrm{CO}$ and $\mathrm{H}_{2}$ was 
calculated by PVT Sim. The solubility of pure component gas in reservoir brine and crude oil is provided in Table 5

Storage capacity of each component of flue gas in reservoir can be calculated.

When the theoretical storage capacity of a component is greater than the cumulative injection volume of that, which indicates that the storage capacity of the component as free gas phase in cores is 0 .

Storage capacity of each component of flue gas in reservoir brine can be calculated:

$V_{\text {sto(in water),com }}=S_{\text {com(in water) }} \cdot\left(V_{\text {cum,inj,w }}-V_{\text {cum,pro,w }}\right) \cdot B_{\text {com }}$

where $V_{\text {sto(in water),com }}$ is the storage capacity of each component in reservoir brine, $\mathrm{cm}^{3} ; S_{\text {com(in water) }}$ is the solubility of each component in reservoir brine, $\mathrm{cm}^{3} / \mathrm{cm}^{3}$; and $V_{\text {cum,inj,w }}$ is the cumulative volume of injection water, $\mathrm{cm}^{3} ; V_{\text {cum,pro,w }}$ is the cumulative volume of produced water, $\mathrm{cm}^{3} ; B_{\text {com }}$ is the volume factor of each component gas, $\mathrm{cm}^{3} / \mathrm{cm}^{3}$.

Storage capacity of each component of flue gas in reservoir oil can be calculated:

$V_{\text {sto(in oil),com }}=V_{\text {cum,inj,g }} \cdot X_{\text {com }}-V_{\text {sto(in water),com }}$

where $V_{\text {sto(in oil),com }}$ is the storage capacity of each component in reservoir oil, $\mathrm{cm}^{3}$ and $X_{\text {com }}$ is the mole fraction of each component of the injection gas.

If $G O R_{\mathrm{p}} \leq G O R_{\mathrm{i}}$, the storage capacity of each component of flue gas in the cores can be calculated by the following equations:

(1) Storage capacity of each component of flue gas as free gas phase in cores can be calculated:

$V_{\text {sto(as free gas),com }}=V_{\text {cum,inj,g }} \cdot X_{\text {com }}-V_{\text {sto(in water),com }}-V_{\text {sto(in oil),com }}$

where $V_{\text {sto(as free gas),com }}$ is the storage capacity of each component as free gas phase in cores, $\mathrm{cm}^{3}$.

(2) Storage capacity of each component of flue gas in reservoir brine can be calculated:

Table 5 Solubility of different gases in reservoir oil and brine $\left(42{ }^{\circ} \mathrm{C}\right.$, $8 \mathrm{MPa})$

\begin{tabular}{lcc}
\hline Component & Solubility in oil, $\mathrm{m}^{3} / \mathrm{m}^{3}$ & $\begin{array}{l}\text { Solubility in } \\
\text { water, } \mathrm{m}^{3} / \mathrm{m}^{3}\end{array}$ \\
\hline $\mathrm{CO}_{2}$ & 51.40 & 27.42 \\
$\mathrm{CH}_{4}$ & 11.86 & 1.65 \\
$\mathrm{~N}_{2}$ & 4.22 & 0.97 \\
$\mathrm{O}_{2}$ & 8.57 & 0.0268 \\
$\mathrm{CO}$ & 5.27 & 0.0196 \\
$\mathrm{H}_{2}$ & 3.82 & 0.0115 \\
\hline
\end{tabular}

$$
V_{\text {sto(in water),com }}=S_{\text {com(in water) }} \cdot\left(V_{\text {cum,inj,w }}-V_{\text {cum,pro,w }}\right) \cdot B_{\text {com }}
$$

(3) Storage capacity of each component of flue gas in reservoir oil can be calculated:

$V_{\text {sto(in oil }), \text { com }}=\left[V_{\mathrm{p}} \cdot\left(1-S_{\mathrm{wi}}\right)-V_{\text {cum,pro,o }}\right] \cdot S_{\text {com(in oil })} \cdot B_{\text {com }}$

where $V_{\mathrm{p}}$ is the pore volume of long cores, $\mathrm{cm}^{3} ; S_{\mathrm{wi}}$ is the bound water saturation of long cores, $\%$; $V_{\text {cum,pro,o }}$ is the cumulative volume of produced oil, $\mathrm{cm}^{3}$; and $S_{\text {com(in oil) }}$ is the solubility of individual component in reservoir oil, $\mathrm{cm}^{3} / \mathrm{cm}^{3}$.

If $G O R_{\mathrm{p}}>G O R_{\mathrm{i}}$, the storage capacity of each component of flue gas in cores can be calculated by the following equations:

(1) Storage capacity of each component of flue gas as free gas phase in cores can be calculated:

$V_{\text {sto(as free gas),com }}=V_{\text {sto,inj,g }} \cdot X_{\text {com }}-V_{\text {sto(in water),com }}-V_{\text {sto(in oil),com }}$

(2) Storage capacity of each component of flue gas in reservoir brine can be calculated:

$V_{\text {sto(in water),com }}=S_{\text {com(in water) }} \cdot\left(V_{\text {cum,inj,w }}-V_{\text {cum,pro,w }}\right) \cdot B_{\text {com }}$

(3) Storage capacity of each component of flue gas in reservoir oil can be calculated:

$V_{\text {sto(in oil }), \text { com }}=\left[V_{\mathrm{p}} \cdot\left(1-S_{\mathrm{wi}}\right)-V_{\text {cum,pro,o }}\right] \cdot S_{\text {com(in oil })} \cdot B_{\text {com }}$

\section{Results and discussion}

In this study, continuous waterflooding experiment and flue gas-water-alternating injection after continuous water injection experiment were performed to study the flue gas storage and EOR. In a continuous waterflooding experiment, the continuous injection of water was performed until the water cut is $100 \%$ (no more oil is produced). Then, as an improved flue gas-EOR method, the flue gas-WAG flooding was applied to increase the oil recovery over the continuous waterflooding. More details about the experimental data and results are listed in Table 6.

\subsection{EOR of flue gas-WAG flooding}

Compared with waterflooding, the EOR mechanism of flue gas-WAG flooding is that water-alternating flue gas injection can change the water oil mobility ratio and strengthen the exchange, diffusion, and imbibition of oil, gas, and water three-phase molecules. With the effect of gravity 
Table 6 Experimental data and results of waterflooding and flue gas-WAG flooding

\begin{tabular}{|c|c|c|c|c|}
\hline $\begin{array}{l}\text { Cumulative injection volume, } \\
\text { HCPV }\end{array}$ & $\begin{array}{l}\text { Production gas oil ratio, } \mathrm{m}^{3} / \\
\mathrm{m}^{3}\end{array}$ & Water cut, $\%$ & $\begin{array}{l}\text { Cumulative oil recovery fac- } \\
\text { tor, } \%\end{array}$ & Injection medium \\
\hline 0.1 & 37 & 0.00 & 9.97 & Water \\
\hline 0.2 & 37 & 0.00 & 19.43 & Water \\
\hline 0.3 & 37 & 1.83 & 29.00 & Water \\
\hline 0.4 & 37 & 1.13 & 39.83 & Water \\
\hline 0.5 & 37 & 61.55 & 44.19 & Water \\
\hline 0.6 & 31 & 87.74 & 45.66 & Water \\
\hline 0.7 & 37 & 88.09 & 46.90 & Water \\
\hline 0.8 & 37 & 93.88 & 47.65 & Water \\
\hline 0.9 & 37 & 95.12 & 48.15 & Water \\
\hline $1(0)$ & 37 & 98.89 & 48.27 & Water \\
\hline $1.1(0.1)$ & 37 & 97.44 & 48.77 & Flue gas \\
\hline $1.2(0.2)$ & 35 & 80.21 & 49.82 & Water \\
\hline $1.3(0.3)$ & 39 & 74.19 & 51.55 & Flue gas \\
\hline $1.4(0.4)$ & 35 & 69.40 & 53.86 & Water \\
\hline $1.5(0.5)$ & 36 & 69.22 & 56.85 & Flue gas \\
\hline $1.6(0.6)$ & 43 & 56.46 & 60.21 & Water \\
\hline $1.7(0.7)$ & 128 & 77.73 & 62.78 & Flue gas \\
\hline $1.8(0.8)$ & 458 & 54.52 & 64.03 & Water \\
\hline $1.9(0.9)$ & 514 & 84.83 & 65.02 & Flue gas \\
\hline $2(1.0)$ & 453 & 58.65 & 66.52 & Water \\
\hline $2.1(1.1)$ & 562 & 86.96 & 68.01 & Flue gas \\
\hline $2.2(1.2)$ & 630 & 61.58 & 69.26 & Water \\
\hline $2.3(1.3)$ & 4764 & 96.73 & 69.51 & Flue gas \\
\hline $2.4(1.4)$ & 55,357 & 99.30 & 69.52 & Water \\
\hline
\end{tabular}

The number in brackets in the first column is the cumulative injection volume of flue gas-WAG flooding

differentiation, the high-permeability zone is sealed by injection water, and the micropores are swept by injection gas. The process of flue gas-WAG flooding is a dynamic process, the binding state of water in pores is constantly broken and rebuilt, the alternating plugging of macropores by injected water weakens the breakthrough effect of injection gas, the water injection profile is improved, the water breakthrough time is delayed, and the oil recovery is improved. For the reservoir with serious heterogeneity, the dynamic plugging produced by flue gas-WAG flooding can further improve the effect of WAG flooding. As shown in Fig. 2, in the waterflooding process, the oil recovery factor increases with an increase in injection volume. When the cumulative injection volume reaches $0.5 \mathrm{HCPV}$, the water cut increases significantly to $61.55 \%$. The water cut increase is an indication of water breakthrough occurring in the cores, and the oil recovery factor at water breakthrough is $44.19 \%$. After water breakthrough, the oil recovery factor increases slightly. Further water injection does not significantly improve oil recovery. The ultimate recovery factor of the waterflooding process reaches $48.27 \%$ at $1.0 \mathrm{HCPV}$. In the flue gas-WAG flooding process, before the flue gas breakthrough (1.7 HCPV), the oil recovery factor is increasing gradually with an increase in the WAG injection volume. Meanwhile, the water cut decreases significantly. The water cut declines from $98.89 \%$ to $56.46 \%$. This result indicates that flue gas-WAG flooding can significantly reduce water cut and increase oil recovery factor. When the cumulative injection volume reaches 1.7 HCPV, the production gas-oil ratio increases to $128 \mathrm{~m}^{3} / \mathrm{m}^{3}$, which means that flue gas breakthrough occurs. The corresponding oil recovery factor at gas breakthrough is $62.78 \%$. Similar to the waterflooding process, once gas breakthrough occurs in the core, the oil recovery factor will be affected. After the flue gas breakthrough (1.7 HCPV), the water cut fluctuates greatly with an increase in the WAG injection volume. The ultimate recovery factor of the WAG flooding process reaches $69.52 \%$. Compared with the waterflooding process, the oil recovery factor of flue gas-WAG flooding is increased by $21.25 \%$. Therefore, we can conclude that flue gas-WAG flooding 

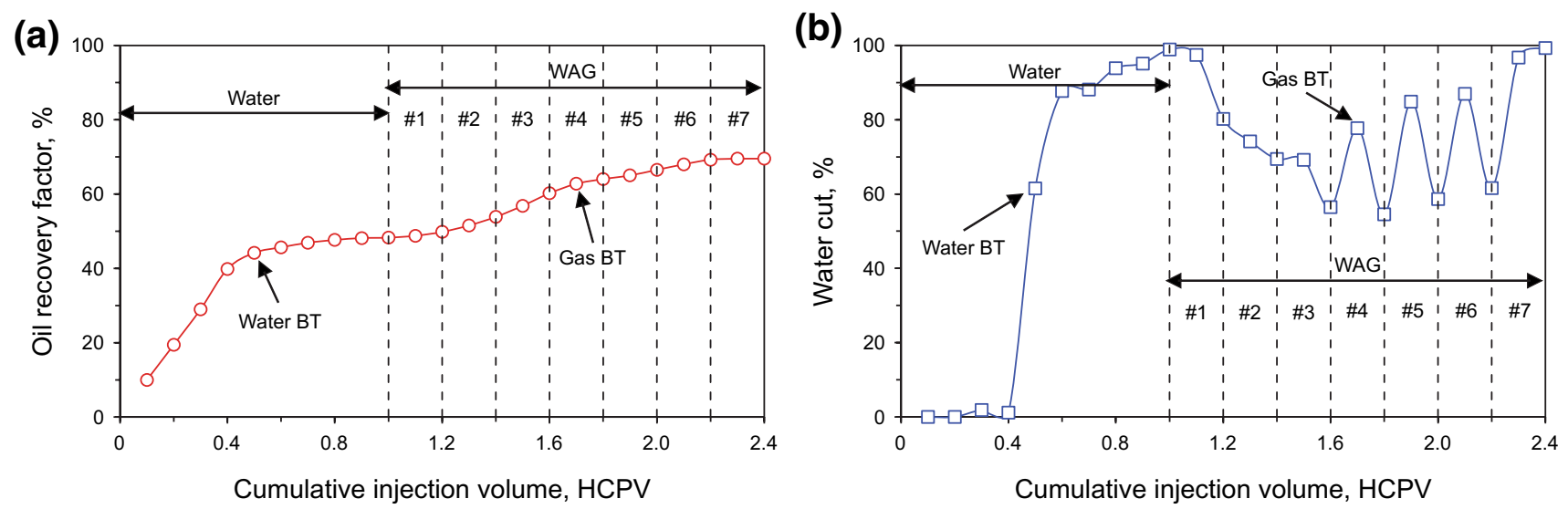

Fig. 2 Oil recovery factor and water cut of waterflooding and flue gas-WAG flooding process (BT: breakthrough)

combines the advantages of the microscopic displacement efficiency of gas flooding and the macroscopic sweep efficiency of waterflooding. Flue gas-WAG flooding after continuous waterflooding can further enhance oil recovery and reduce the water cut, but the efficiency of the flue gas-WAG flooding is strongly dependent on the injection volume.

\subsection{Flue gas storage}

\subsubsection{Total storage capacity}

We can determine the flue gas storage capacity according to Sect. 3.1 to investigate flue gas storage in the flue gas-WAG flooding process. The flue gas storage ratio is defined as the storage capacity (reservoir condition) of flue gas in cores divided by the cumulative injection volume (reservoir conditions) of flue gas. The storage ratio and storage capacity of flue gas in the flue gas-WAG flooding process are shown in Fig. 3.

It can be seen from Fig. 3 that before gas breakthrough ( $0.7 \mathrm{HCPV})$, the flue gas storage ratio is almost maintained at $100 \%$. This shows that the injection gas is completely stored in cores, and the flue gas storage capacity increases gradually. Afterward, with an increase in injection volume, when the cumulative injection volume reaches 0.7 $\mathrm{HCPV}$, the flue gas storage ratio starts to decrease gradually. When the injection gas breakthrough occurs, injection gas no longer dissolves in oil and water, which results in flue gas storage ratio decrease. The storage capacity of flue gas reaches $50.89 \mathrm{~cm}^{3}$, which is the maximum of storage capacity in the flue gas-WAG flooding process. After gas breakthrough occurs at $0.7 \mathrm{HCPV}$, the storage ratio does not decline significantly, which still maintains at a high level (0.93). Afterward, the flue gas storage ratio shows a nearly linear decline trend. At the end of the flue gas-WAG flooding process, the flue gas storage ratio is only $16 \%$. The reason for significant decrease in storage ratio is that when the injection gas breakthrough occurs in the cores, partial free gas is displaced by water slug, and a large amount of injection gas is produced. These results demonstrated that once the injection volume reached a certain critical level, the sole increase in injection volume is not effective in enhancing the storage capacity. Therefore, determination of the injection volume of gas breakthrough occurrence is important for flue gas storage in the flue gas-WAG flooding.

\subsubsection{Storage capacity of each component of flue gas}

The method for calculating the theoretical storage capacity of each component of flue gas in reservoir oil, water, and as free gas is based on the model in Sect. 3.2. Thus, the theoretical storage capacity of each component of flue gas is defined as follows:

$V_{\text {sto(thoretical),com }}=V_{\text {sto(as free gas),com }}+V_{\text {sto(in water),com }}+V_{\text {sto(in oil),com }}$

where $V_{\text {sto(theoretical),com }}$ is the theoretical storage capacity of each component of flue, $\mathrm{cm}^{3}$.

The calculation process of $\mathrm{N}_{2}$ storage capacity was demonstrated as an example. First, the $\mathrm{N}_{2}$ storage capacity in reservoir oil and reservoir water is determined by Eqs. (3) and (4). If theoretical storage capacity of $\mathrm{N}_{2}$ (volume of $\mathrm{N}_{2}$ dissolved in reservoir water plus volume of $\mathrm{N}_{2}$ dissolved in oil) is less than the cumulative injection volume, it means $\mathrm{N}_{2}$ exists as free gas in cores. Second, if $G O R_{\mathrm{p}} \leq G O R_{\mathrm{i}}$, the volume of $\mathrm{N}_{2}$ dissolved in oil and water and the volume of $\mathrm{N}_{2}$ as free gas phase in cores are calculated by Eqs. (5)-(7). If $G O R_{\mathrm{p}}>G O R_{\mathrm{i}}$, the volume of $\mathrm{N}_{2}$ dissolved in water and 


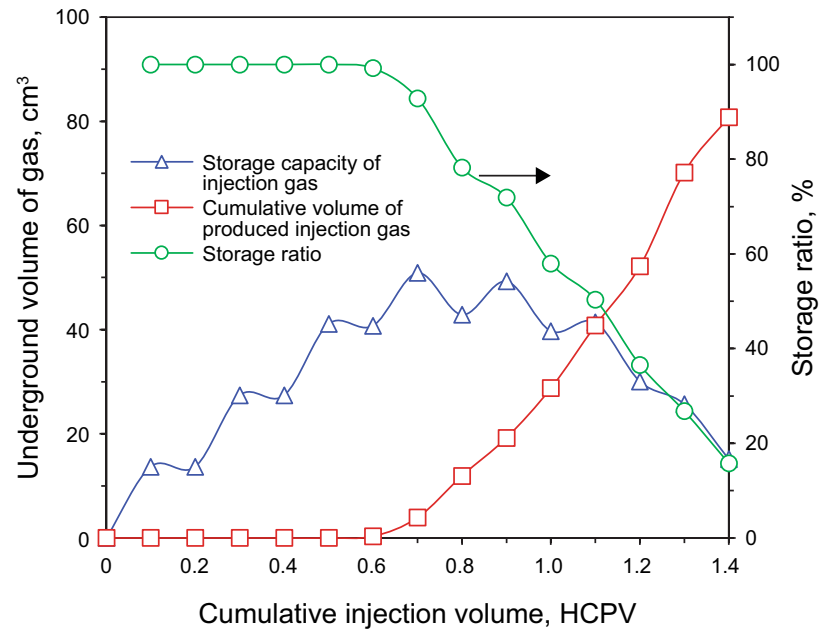

Fig. 3 Flue gas storage capacity in the flue gas-WAG flooding

oil and the volume of the $\mathrm{N}_{2}$ as free gas phase in cores are calculated by Eqs. (8)-(10). Third, the storage capacity of $\mathrm{N}_{2}$ is equal to the sum of the volume of $\mathrm{N}_{2}$ dissolved in oil and water and the volume of $\mathrm{N}_{2}$ as free gas phase in cores; then, the calculation of storage capacity of other components can refer to the $\mathrm{N}_{2}$ calculation process. The results are shown in Fig. 4. Except $\mathrm{N}_{2}$, the theoretical storage capacities of other gases are larger than their actual injection volume, which means that only $\mathrm{N}_{2}$ exists as free gas phase in cores. Other gases are only dissolved in reservoir brine and crude oil.
As shown in Fig. 5, in the early period of flue gas-WAG flooding, the storage capacity of the individual component increases with an increase in injection volume. After gas breakthrough, the storage capacity of the individual component decreases gradually. It is seen that the storage capacity of $\mathrm{N}_{2}$ is the largest among all components in the flue gas-WAG flooding process. Moreover, the storage capacity of individual component reaches a maximum all at 0.7 HCPV. The storage capacity values of individual component are 42.7, 7.47, 0.25, 0.21, 0.14, and $0.12 \mathrm{~cm}^{3}$ for $\mathrm{N}_{2}, \mathrm{CO}_{2}$, $\mathrm{O}_{2}, \mathrm{CH}_{4}, \mathrm{H}_{2}$, and $\mathrm{CO}$, respectively. Thus, the storage capacity of injection gas mainly consists of $\mathrm{N}_{2}$ and $\mathrm{CO}_{2}$. From Fig. 6, only $\mathrm{N}_{2}$ exists as free gas phase in cores and other components of injection gas are distributed in oil and water. It is clear that, except for $\mathrm{N}_{2}$, the storage capacity of other components in oil is larger than that in water in the flue gas-WAG flooding process; the reason is that the solubility of these components in crude oil is larger than that in reservoir brine. However, after gas breakthrough, the storage capacity of $\mathrm{N}_{2}$ in oil is lower than that in water because the injection volume of $\mathrm{N}_{2}$ is much larger than the theoretical storage capacity of $\mathrm{N}_{2}$ at any time. The reservoir fluids are $\mathrm{N}_{2}$ saturated. With the production of oil and water, the storage capacity of $\mathrm{N}_{2}$ in oil decreases with an increase in injection volume; however, due to the supplement of injected water, the water in cores does not decrease significantly and the storage capacity of $\mathrm{N}_{2}$ in water is maintained at a relatively stable and low level. Moreover, the storage capacity of
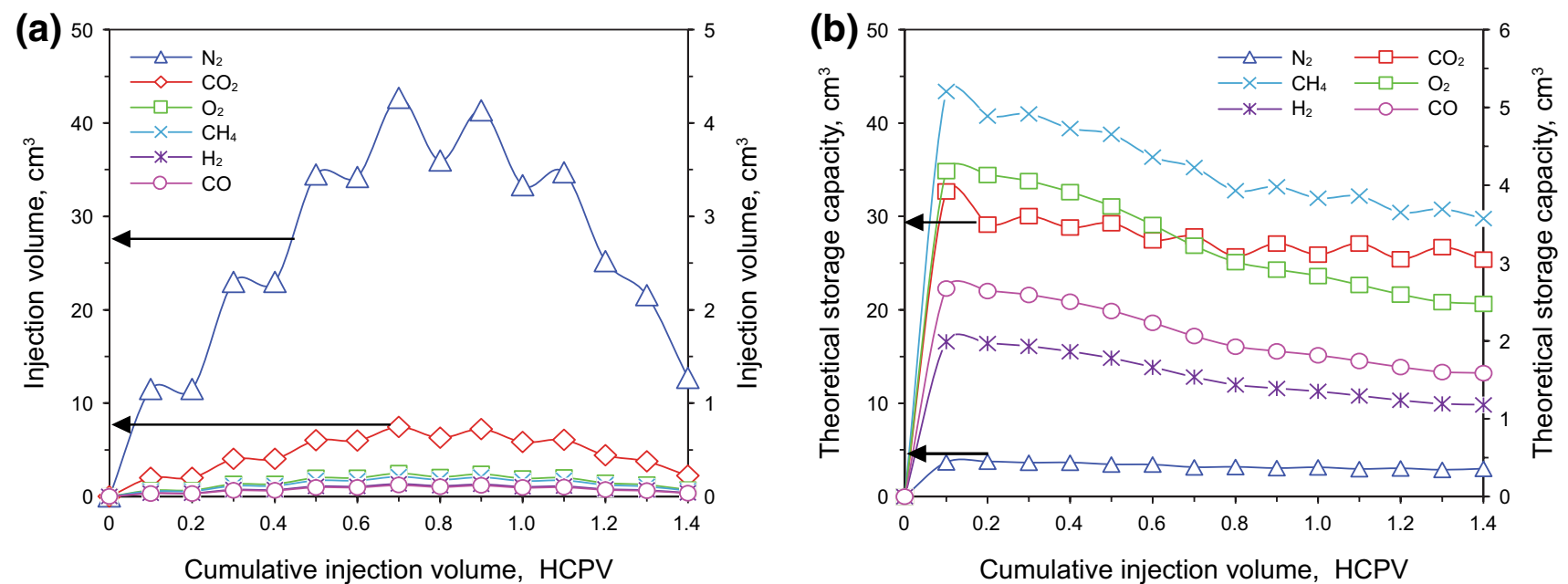

Fig. 4 Injection volume and theoretical storage capacity of each component of flue gas in the flue gas-WAG flooding 


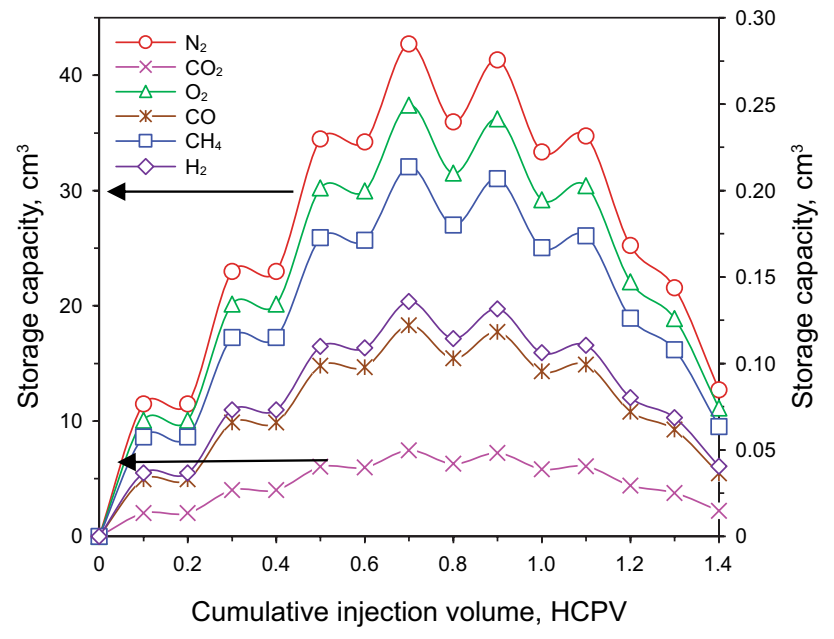

Fig. 5 Storage capacity of each component of flue gas in the flue gasWAG flooding

$\mathrm{N}_{2}$ is mainly composed of that as free gas phase, and its storage capacity as free gas phase reaches as high as $39.55 \mathrm{~cm}^{3}$ at $0.7 \mathrm{HCPV}$ in the flue gas-WAG flooding process, in which the total storage capacity of $\mathrm{N}_{2}$ is $42.7 \mathrm{~cm}^{3}$.

\subsection{Injection strategies for flue gas storage and EOR}

In this study, we can obtain that it is very important to determine the time of flue gas breakthrough in cores for flue gas storage. $0.7 \mathrm{HCPV}$ is the reasonable injection volume to obtain the maximum storage capacity of flue gas while maintaining a higher oil recovery factor in the flue gas-WAG flooding process. The corresponding maximum storage capacity of flue gas $\left(50.89 \mathrm{~cm}^{3}\right)$ and a high oil recovery factor $(62.78 \%)$ are obtained. From the perspective of flue gas storage, the maximum storage ratio of flue gas $(100 \%)$ occurs up to $0.6 \mathrm{HCPV}$ in the flue gas-WAG flooding process and the injection volume of $0.6 \mathrm{HCPV}$ is worth considering. From the perspective of maximizing oil recovery degree, the ultimate oil recovery factor reaches as high as $69.52 \%$ and the injection volume of $1.4 \mathrm{HCPV}$ is the best choice in the flue gas-WAG flooding process. Compared with the waterflooding process, the ultimate oil recovery factor of flue gas-WAG flooding is increased by $21.25 \%$.

\section{Conclusions}

A long-core experimental device was designed and built for evaluating flue gas storage and EOR of flue gas-WAG flooding after continuous waterflooding in oil reservoirs, by which the relationship between flue gas storage and EOR is investigated. A novel material balance model based on different storage mechanisms is proposed. The storage capacity of multicomponent flue gas and storage capacity of each component of flue gas in reservoir oil, water and as free gas in flue gas-WAG flooding can be described.

First, an oil recovery factor as high as $69.52 \%$ is obtained in the flue gas-WAG flooding process applied in a postwaterflooding reservoir. This result indicates that the flue gas-WAG flooding can be an efficient approach to enhance oil recovery.

Second, in the flue gas-WAG flooding process, the storage capacity of flue gas increases with an increase in injection volume; after the gas breakthrough occurs, the storage capacity of flue gas declines gradually. This indicates that once the injection volume reaches a certain critical level, a continuous increase in injection volume alone is not effective in enhancing the storage capacity. Thus, it is very important to determine the time of flue gas breakthrough in cores for flue gas storage.

Third, in the flue gas-WAG flooding process, only $\mathrm{N}_{2}$ exists as free gas phase in cores and other gases are only dissolved in reservoir brine and crude oil. The storage capacity of injection gas mainly consists of $\mathrm{N}_{2}$ and $\mathrm{CO}_{2}$, and the storage capacity of $\mathrm{N}_{2}$ is much higher than that of other components of injection gas.

Fourth, in the flue gas-WAG flooding process, for the maximum storage ratio of injection gas, the injection volume of $0.6 \mathrm{HCPV}$ is the best. For the maximum oil recovery factor, when the injection volume reaches $1.4 \mathrm{HCPV}$, the oil recovery factor is as high as $69.52 \%$. For the combination of flue gas storage and EOR, the recommended injection 

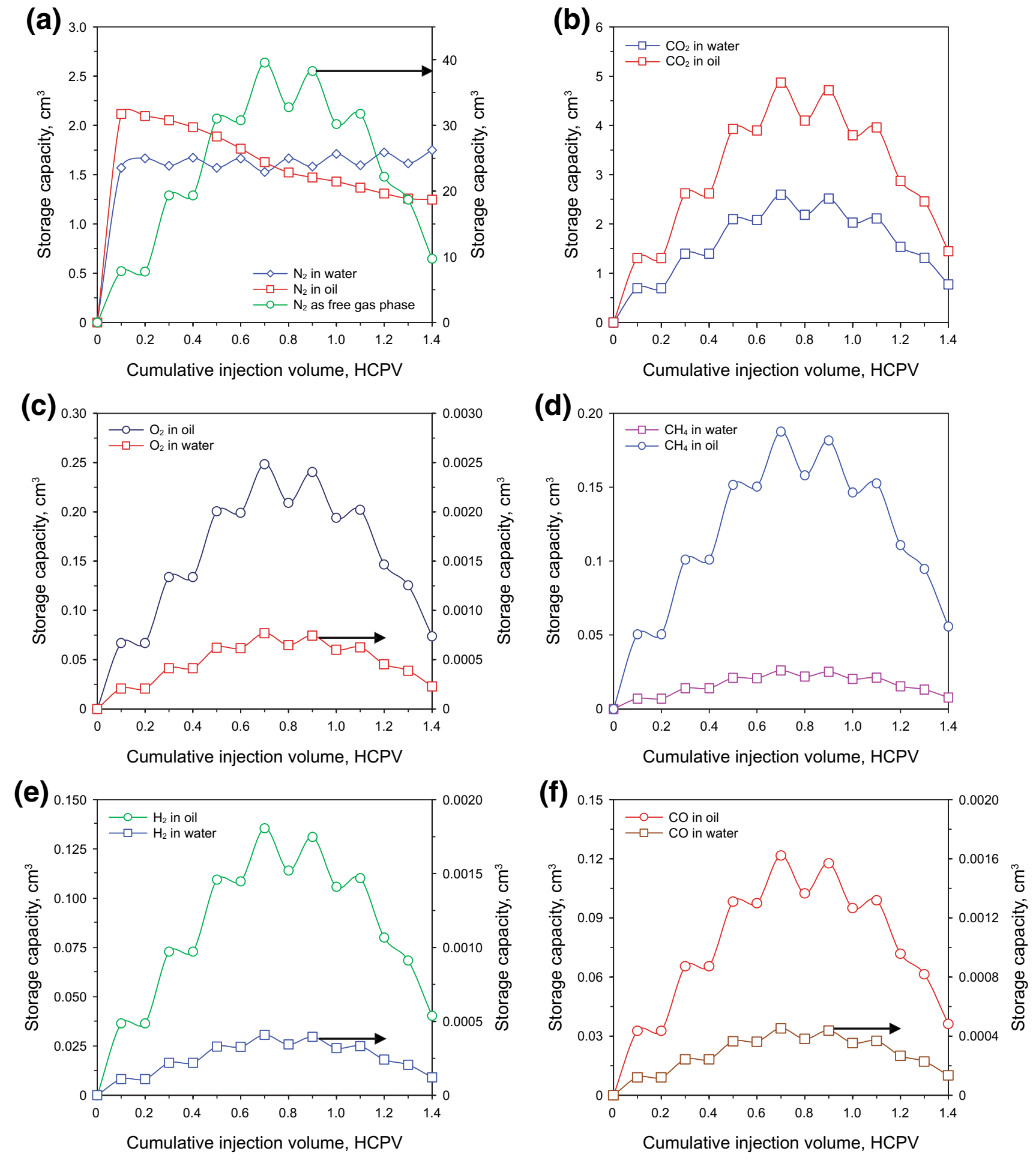

Fig. 6 Storage capacity of each component of flue gas in the flue gas-WAG flooding

volume is $0.7 \mathrm{HCPV}$ and the corresponding flue gas storage ratio and oil recovery factor remain at a high level of $62.78 \%$ and $93 \%$, respectively.
Acknowledgements This work was supported by the Department of Science and Technology of Sichuan Province (2019YFG0457), the National Natural Science Foundation of China (5183000045), the National Major Science and Technology Project of CNPC "Research and Application of Key Technologies for Benefit Development of 
Volcanic Rock Reservoirs" (2017E-04-05), and the PetroChina Major Science and Technology Project (2018E-1805).

Open Access This article is licensed under a Creative Commons Attribution 4.0 International License, which permits use, sharing, adaptation, distribution and reproduction in any medium or format, as long as you give appropriate credit to the original author(s) and the source, provide a link to the Creative Commons licence, and indicate if changes were made. The images or other third party material in this article are included in the article's Creative Commons licence, unless indicated otherwise in a credit line to the material. If material is not included in the article's Creative Commons licence and your intended use is not permitted by statutory regulation or exceeds the permitted use, you will need to obtain permission directly from the copyright holder. To view a copy of this licence, visit http://creativecommons.org/licenses/by/4.0/.

\section{References}

Agartan E, Gaddipati M, Yip Y, et al. $\mathrm{CO}_{2}$ storage in depleted oil and gas fields in the Gulf of Mexico. Int J Greenh Gas Control. 2018;72:38-48. https://doi.org/10.1016/j.ijggc.2018.02.022.

Bachu S. Comparison between methodologies recommended for estimation of $\mathrm{CO}_{2}$ storage capacity in geological media by the CSLF task force on $\mathrm{CO}_{2}$ storage capacity estimation and the USDOE capacity and fairways subgroup of the regional carbon sequestration partnerships program, phase III report. In: Carbon sequestration leadership forum (CSLF), 21 April, 2008, Washington, DC.

Bachu S. Review of $\mathrm{CO}_{2}$ storage efficiency in deep saline aquifers. Int $\mathrm{J}$ Greenh Gas Control. 2015;40:188-202. https://doi.org/10.1016/j. ijggc.2015.01.007.

Bachu S, Shaw JC, Pearson RM. Estimation of oil recovery and $\mathrm{CO}_{2}$ storage capacity in $\mathrm{CO}_{2}$ EOR incorporating the effect of underlying aquifers. In: SPE/DOE symposium on improved oil recovery, 17-21 April, 2004, Tulsa, Oklahoma. https://doi. org/10.2118/89340-MS

Bachu S, Bonijoly D, Bradshaw J, et al. $\mathrm{CO}_{2}$ storage capacity estimation: methodology and gaps. Int $\mathrm{J}$ Greenh Gas Control. 2007;1(4):430-43. https://doi.org/10.1016/S1750-5836(07)00086 -2 .

Bender S, Akin S. Flue gas injection for EOR and sequestration: case study. J Pet Sci Eng. 2017;157:1033-45. https://doi.org/10.1016/j. petrol.2017.07.044.

Berg S, Oedai S, Landman AJ, et al. Miscible displacement of oils by carbon disulfide in porous media: experiments and analysis. Phys Fluids. 2010;22:113102. https://doi.org/10.1063/1.3516614.

Berg S, Oedai S, Ott H. Displacement and mass transfer between saturated and unsaturated $\mathrm{CO}_{2}$-brine systems in sandstone. Int $\mathrm{J}$ Greenh Gas Control. 2013;12:478-92. https://doi.org/10.1016/j. ijggc.2011.04.005.

Bürkle S, Becker LG, Dreizler A, et al. Experimental investigation of the flue gas thermochemical composition of an oxy-fuel swirl burner. Fuel. 2018;231:61-72. https://doi.org/10.1016/j. fuel.2018.05.039.

Ding SW, Xi Y, Jiang HQ. $\mathrm{CO}_{2}$ storage capacity estimation in oil reservoirs by solubility and mineral trapping. Appl Geochem. 2018;89:121-8. https://doi.org/10.1016/j.apgeochem.2017.12.002.

Dong M, Huang S. Flue gas injection for heavy oil recovery. J Can Pet Technol. 2002;41(9):44-50. https://doi.org/10.2118/02-09-04.

Edwards Ryan WJ, Celia MA, Bandilla KW, et al. A model to estimate carbon dioxide injectivity and storage capacity for geological sequestration in shale gas wells. Environ Sci Technol. 2015;49:9222-9. https://doi.org/10.1021/acs.est.5b01982.
Ettehadtavakkol A, Lake LW, Bryant SL. $\mathrm{CO}_{2}$-EOR and storage design optimization. Int J Greenh Gas Control. 2014;25:79-92. https:// doi.org/10.1016/j.ijggc.2014.04.006.

Farajzadeh R, Eftekhari AA, Dafnomilis G, et al. On the sustainability of $\mathrm{CO}_{2}$ storage through $\mathrm{CO}_{2}$-enhanced oil recovery. Appl Energy. 2020;261:114467. https://doi.org/10.1016/j.apene rgy.2019.114467.

Fong WS, Tang RW, Emanuel AS, et al. EOR for California Diatomites: $\mathrm{CO}_{2}$, flue gas and water corefloods, and computer simulations. In: SPE western regional meeting, 30 March-1 April, 1992, Bakersfield, California. https://doi.org/10.2523/24039-MS.

Forooghi A, Hamouda AA, Eilertsen T. Co-optimization of $\mathrm{CO}_{2}$ EOR and sequestration process in a North Sea chalk reservoir. In: SPE/EAGE reservoir characterization and simulation conference, 19-21 October, 2009, Abu Dhabi, UAE. https://doi. org/10.2118/125550-MS.

Fossum B, Blaker T, Brendsdal E, et al. Numerical simulation of hot-water and flue-gas injection under typical North Sea Reservoir conditions. In: SPE/DOE enhanced oil recovery symposium, 22-24 April, 1992, Tulsa, Oklahoma. https://doi. org/10.2118/24168-MS.

Ghomian Y, Pope GA, Sepehrnoori K. Economical co-optimization of $\mathrm{CO}_{2}$ sequestration and enhanced oil recovery. In: Sixth annual conference on carbon capture and sequestration proceeding, 7-10 May, 2007, Pittsburgh, PA.

Godec M, Kuuskraa V, Leeuwen TV, et al. $\mathrm{CO}_{2}$ storage in depleted oil fields: the worldwide potential for carbon dioxide enhanced oil recovery. Energy Procedia. 2011;4:2162-9. https://doi. org/10.1016/j.egypro.2011.02.102.

Gozalpour F, Ren SR, Tohidi B. $\mathrm{CO}_{2}$ EOR and storage in oil reservoir. Oil Gas Sci Technol. 2005;60(3):537-46. https://doi.org/10.2516/ ogst:2005036.

Han HS, Li S, Ma DS. Investigation of flue gas displacement and storage after the water flooding in a full diameter conglomerate longcore. Pet Explor Dev. 2018;45(5):903-9. https://doi.org/10.11698 /PED.2018.05.10.

Jahangiri HR, Zhang, DX. Optimization of the net present value of carbon dioxide sequestration and enhanced oil recovery. In: Offshore technology conference, 2-5 May, 2011, Houston, Texas. https:// doi.org/10.4043/21985-MS.

Jia B, Tsau JS, Barati R. A review of the current progress of $\mathrm{CO}_{2}$ injection EOR and carbon storage in shale oil reservoirs. Fuel. 2019;236:404-27. https://doi.org/10.1016/j.fuel.2018.08.103.

Kopp A, Class $\mathrm{H}$, Helming R. Investigations on $\mathrm{CO}_{2}$ storage capacity in saline aquifers-Part 2: estimation of storage capacity coefficients. Int J Greenh Gas Control. 2009a;3(3):277-87. https://doi. org/10.1016/j.ijggc.2008.10.001.

Kopp A, Class $\mathrm{H}$, Helming R. Investigations on $\mathrm{CO}_{2}$ storage capacity in saline aquifers. Part 1. Dimensional analysis of flow processes and reservoir characteristics. Int J Greenh Gas Control. 2009b;3(3):263-76. https://doi.org/10.1016/j.ijggc.2008.10.002.

Leach A, Mason CF, Veld KVT. Co-optimization of enhanced oil recovery and carbon sequestration. Resour Energy Econ. 2011;33(4):893-912. https://doi.org/10.1016/j.resen eeco.2010.11.002.

Lee JS, Kim JH, Kim JT, et al. Adsorption equilibria of $\mathrm{CO}_{2}$ on zeolite $13 \mathrm{X}$ and zeolite X/activated carbon composite. J Chem Eng Data. 2002;47:1237-42. https://doi.org/10.1021/je020050e.

Li ZW, Dong MZ, Li SL, et al. $\mathrm{CO}_{2}$ sequestration in depleted oil and gas reservoirs-caprock characterization and storage capacity. Energy Convers Manag. 2006a;47:1372-82. https://doi. org/10.1016/j.enconman.2005.08.023.

Li ZW, Dong MZ, Li SL, et al. $\mathrm{CO}_{2}$ sequestration in depleted oil and gas reservoirs-caprock characterization and storage capacity. Energy Convers Manag. 2006b;47(11):1372-82. https://doi. org/10.1016/j.enconman.2005.08.023. 
Liu QY, Liu ZY, Wu WZ. Effect of $\mathrm{V}_{2} \mathrm{O}_{5}$ additive on simultaneous $\mathrm{SO}_{2}$ and $\mathrm{NO}$ removal from flue gas over a monolithic cordierite-based $\mathrm{CuO} / \mathrm{Al}_{2} \mathrm{O}_{3}$ catalyst. Catal Today. 2009;147:S285-9. https://doi. org/10.1016/j.cattod.2009.07.013.

Liu RG, Zhang JG, Meng L, et al. Feasibility study of steam/flue gas mixture injection in low permeability reservoir. In: SPE project and facilities challenges conference at METS, 13-16 February, 2011, Doha, Qatar. https://doi.org/10.2118/142343-MS.

López D, Buitrago R, Sepúlveda-Escribano A, et al. Surface complexes formed during simultaneous catalytic adsorption of $\mathrm{NO}$ and $\mathrm{SO}_{2}$ on activated carbons at low temperatures. J Phys Chem C. 2007;111:1417-23. https://doi.org/10.1021/jp063544h.

Majeed H, Svendsen HF. Characterization of aerosol emissions from $\mathrm{CO}_{2}$ capture plants treating various power plant and industrial flue gases. Int J Greenh Gas Control. 2018;74:282-95. https://doi. org/10.1016/j.ijggc.2018.04.016.

Nasralla RA, Snippe JR, Farajzadeh R. Coupled geochemical-reservoir model to understand the interaction between low salinity brines and carbonate rock. In: SPE Asia Pacific enhanced oil recovery conference, 11-13 August, 2015, Kuala Lumpur, Malaysia. https ://doi.org/10.2118/174661-MS.

Santibanez-Borda E, Govindan R, Elahi N. Maximising the dynamic $\mathrm{CO}_{2}$ storage capacity through the optimisation of $\mathrm{CO}_{2}$ injection and brine production rates. Int J Greenh Gas Control. 2019;80:7695. https://doi.org/10.1016/j.ijggc.2018.11.012.

Shaw J, Bachu S. Screening, evaluation, and ranking of oil reservoirs suitable for $\mathrm{CO}_{2}$ flood EOR and carbon dioxide sequestration. J Can Pet Technol. 2002;41(9):51-61. https://doi. org/10.2118/02-09-05.

Shokoya OS, Mehta SA, Moore RG, et al. Effect of oil and flue-gas compositions on oil recovery in the flue-gas/light-oil injection process. In: SPE annual technical conference and exhibition, 9-12 October, 2005, Dallas, Texas. https://doi.org/10.2118/97262-MS.

Snippe J, Berg S, Ganga K, et al. Experimental and numerical investigation of wormholing during $\mathrm{CO}_{2}$ storage and water alternating gas injection. Int J Greenh Gas Control. 2020;94:102901. https:// doi.org/10.1016/j.ijggc.2019.102901.

Srivastava RK, Huang SS, Dong MZ. Comparative effectiveness of $\mathrm{CO}_{2}$ produced gas, and flue gas for enhanced heavy-oil recovery. SPE Reservoir Eval Eng. 1999;2(3):238-47. https://doi. org/10.2118/56857-PA.

Test method for reservoir fluid physical properties: GB/T 26981-2011. Research Institute of Petroleum Exploration and Development 2012. Beijing: Standards Press of China.
Sumathi S, Bhatia S, Lee KT, et al. Adsorption isotherm models and properties of $\mathrm{SO}_{2}$ and $\mathrm{NO}$ removal by palm shell activated carbon supported with cerium (Ce/PSAC). J Hazard Mater. 2010a;162:194-200. https://doi.org/10.1016/j.cej.2010.05.028.

Sumathi S, Bhatia S, Lee KT, et al. Selection of best impregnated palm shell activated carbon (PSAC) for simultaneous removal of $\mathrm{SO}_{2}$ and $\mathrm{NO}_{X}$. J Hazard Mater. 2010b;176:1093-6. https://doi. org/10.1016/j.jhazmat.2009.11.037.

Trevisan OV, Laboissiere P, Monte-Mor S. Laboratory study on steam and flue gas co-injection for heavy oil recovery. In: SPE heavy oil conference-Canada, 11-13 June, 2013, Calgary, Alberta. https:// doi.org/10.2118/165523-MS.

Trivedi JJ, Babadagli T. CO and flue gas sequestration during tertiary oil recovery: optimal injection strategies and importance of operational parameters. In: Canadian international petroleum conference, 7-9 June, 2005, Calgary, Alberta. https://doi. org/10.2118/2005-042.

U.S.DOE (U.S. Department of Energy). Carbon sequestration Atlas of the United States and Canada. 2nd ed. Pittsburgh, PA: National Energy Technology Laboratory; 2008.

van der Meer LGH, Yavuz F. $\mathrm{CO}_{2}$ storage capacity calculations for the Dutch subsurface. Energy Procedia. 2009;1(1):2615-22. https:// doi.org/10.1016/j.egypro.2009.02.028.

Yi $\mathrm{HH}$, Wang ZX, Liu HY, et al. Adsorption of $\mathrm{SO}_{2}, \mathrm{NO}$, and $\mathrm{CO}_{2}$ on activated carbons: equilibrium and thermodynamics. J Chem Eng Data. 2014;59:1556-63. https://doi.org/10.1021/je4011135.

Zangeneh H, Jamshidi S, Soltanieh M. Coupled optimization of enhanced gas recovery and carbon dioxide sequestration in natural gas reservoirs: case study in a real gas field in the south of Iran. Int J Greenh Gas Control. 2013;17:515-22. https://doi.org/10.1016/j. ijggc.2013.06.007.

Zhang L, Ren B, Huang HD, et al. $\mathrm{CO}_{2}$ EOR and storage in Jilin oilfield China: monitoring program and preliminary results. J Pet Sci Eng. 2015;125:1-12. https://doi.org/10.1016/j.petrol.2014.11.005.

Zheng Z, Larson ED, Li Z, et al. Near-term mega-scale $\mathrm{CO}_{2}$ capture and storage demonstration opportunities in China. Energy Environ Sci. 2010;3:1153-69. https://doi.org/10.1039/B924243K.

Zhou D, Zhao ZX, Liao J, et al. A preliminary assessment on $\mathrm{CO}_{2}$ storage capacity in the Pearl River Mouth Basin offshore Guangdong. China Int J Greenh Gas Control. 2011;5(2):308-17. https://doi. org/10.1016/j.ijggc.2010.09.011.

Zhou X, Yuan QW, Rui ZH, et al. Feasibility study of $\mathrm{CO}_{2}$ huff 'n' puff process to enhance heavy oil recovery via long core experiments. Appl Energy. 2019;236:526-39. https://doi.org/10.1016/j.apene rgy.2018.12.007. 